\title{
Exposure Laterality
}

National Cancer Institute

\section{Source}

National Cancer Institute. Exposure Laterality. NCI Thesaurus. Code C123973.

A qualifier for the side of the body the exposure assessment is performed. 